\title{
Study on the Cultivation of Applied Talents and the Reform of Curriculum System in Universities Based on the Integration of Production, Teaching and Research
}

\author{
Li Yangyang1, Ma Lisha ${ }^{2}$ \\ ${ }^{1}$ Yunnan Technology and Business University, Kunming, Yunnan, 651700 \\ ${ }^{2}$ Yunnan College of Business Management, Kunming, Yunnan, 650106
}

Keywords: Application of Technical Personnel, Training Mechanism, Production and Study

\begin{abstract}
At present, the cultivation of excellent applied technical talents in Chinese universities is mainly induced by interests, which leads to the vacancy in the field of personnel training in colleges and universities in China and its disconnection from practice, causing distortion of teaching of applied skills. The basic principle of industry-university-institute cooperation education is that industry-academia cooperation and two-way participation are involved. The ways and methods of implementation are combinations of work and study and practice of setting posts. The goal to be achieved is to comprehensively improve the overall quality of students in order to meet the needs of talent development in the market economy. China can cultivate "orientation" for outstanding applied technical talents from the value norms of educating people and employing depth, and cultivate "setting" for excellent applied technical talents from the instructional plan of integrating theory and practice. From policy and law Rectification of institutional rules for the excellent application of skilled personnel training "style." Based on the research of some theory and practice workers over the years, this paper expounds the basic conceptions and characteristics of cooperative education of production, study and research, the reasons and the scope of the cooperative education of production, study and research in China, the differences and basic conditions between them and conventional production practice, education, teaching and social effects.
\end{abstract}

\section{Introduction}

On May 4, 2010, the "Opinions on Vigorously Promoting Innovation and Entrepreneurship in Colleges and Universities and Undertaking Entrepreneurship by Students" clearly pointed out that "innovation education is a teaching concept and mode ". On June 6, 2010, China promulgated the "National Medium and Long-term Talents Development Plan (2010-2020)" and pointed out: "At present, the overall level of talent development in our country still lags behind that of our country's economic and social development. Place ", of which the first two are" lack of high-level innovative talents "and" talent innovation ability is not strong "[1]. Practice has proved that the cooperative education of production, study and research is an effective way to train creative talents.

\section{The Concept of the Integration of Production, Teaching and Research}

From the concept of the size of view, the combination of production, study and research contains the content of cooperative education. However, in actual use, the combination of production, study and research usually does not include personnel training content into its content, at least many people do not yet know it. The so-called combination of production, learning and research refers to the process or activity of organically combining and coordinating the development of production units, colleges and universities and research institutes. Its main contents are the transformation of scientific research achievements and the development and application of products and technologies. Based on the research of some theoretic and practical workers over the years, the author thinks that the basic connotation of cooperative education of production, study and research can be summed up as follows: It is a method which focuses on cultivating students' overall quality, comprehensive 
ability and employment competitiveness, using schools and enterprises two different educational environments and educational resources, take classroom teaching and students to participate in practical work organically, to develop suitable for different employers need, with a comprehensive quality and innovative ability of the education model.[1] Its basic principle is that industry-academy cooperation and two-way participation are involved. The ways and methods for its implementation are the combination of work and study and the practice of setting posts. The goal to be achieved is to comprehensively improve the overall quality of students and meet the needs of talent development in the market economy.

\section{The Characteristic of Combination of Integration of Production, Teaching and Research}

The combination of production, study and research is an important feature of engineering education, the essential requirement of engineering education, and the open education model, which is an advanced form of engineering practice education. The core of the combination of production, study and research is education, the main body is a student, the purpose is to improve students' ability to adapt to society and production. [2] The essence is the combination of educational learning and engineering practice. The basic characteristics are as follows:

\subsection{Create a community of engineering practice teaching}

Engineering education is an open and complex artificial system, which means that engineering education cannot be considered only in higher education. Production, teaching and research cooperation in running schools can integrate scientific research, production and education into a whole. By reasonably arranging the three to effectively cooperate with each other, it not only achieves the goal of education for production and scientific research, but also provides corresponding training for professionals of engineering education environment, so that the combination of theory and practice, which will greatly benefit the engineering practice teaching quality and level of improvement. [3]

\subsection{Create engineering practice teaching internal and external hardware support environment}

Engineering practice education needs internal and external environment support. In order to keep the engineering practice environment of colleges and universities in pace with the development of social economy and construction, it can not be realized by relying solely on the state's investment. Practice has proved that colleges and universities in cooperation in running schools can seek partners, make full use of social idle assets, rich intellectual resources and business financial resources to make up for lack of investment in school engineering practice environment, to achieve resource sharing and enhance the strength of running a school, Improve school efficiency.

\subsection{Enhance teachers' research and practical ability}

Combination of industry, university and research education. Some teaching activities carried out in the enterprise, requiring teachers must be familiar with the enterprise's industrial environment, technology development and production and operation. In this way, it not only provides opportunities for teachers to further integrate theory with practice, solve practical problems in engineering production and improve their own teaching and research level, but also provides opportunities for young teachers to contact with society, understand society, understand production practices and enhance engineering awareness, teaching type "to" teaching and research type ", train" double-qualified "teachers and at the same time promote the development of science and technology personnel to compound talents[3].

\subsection{Establish a new knowledge system of engineering practice education}

Through the combination of industry, education and research, the school can widely listen to the views of enterprises and scientific and technological communities on teaching plans and curriculums of engineering practice, understand more deeply and truly the needs of society and 
enhance their initiative in response to them. It can create a better Education environment conducive to the training of personnel adapted to the development of enterprises and society; can make the school's professional settings, training programs, teaching content and practice links closer to the needs of social development, and build a more scientific and perfect new system of engineering practice knowledge. In the new teaching system, some typical modern scientific methods and innovative examples of new materials, new technologies and new techniques from research and production frontlines enable students to acquire the latest cutting-edge scientific and technological knowledge, broaden their horizons and enhance their awareness of engineering [3].

\section{China's Model of Integration of Production, Teaching and Research}

The key to cooperative education among production, study and research lies in the effective integration and utilization of complementary resources of universities, research institutes and enterprises. Judging from the current situation in our country, although many universities, research institutes and enterprises have explored various modes of cooperative education among themselves, the cooperative relations among industries, universities and research institutes are rather loose and there is no effective mechanism for training innovative personnel.

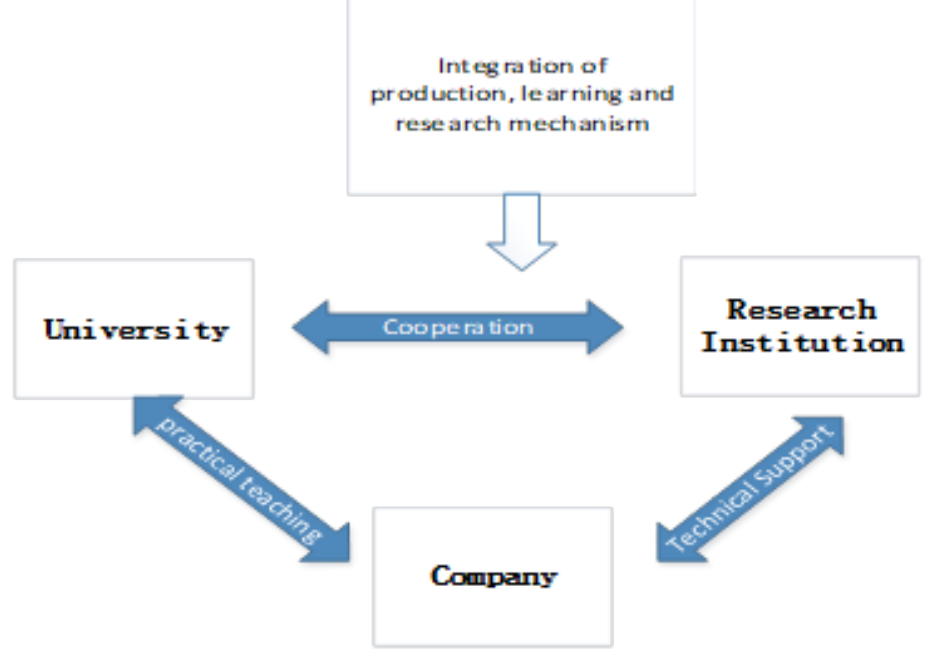

Figure 1 China's Model of Integration of Production, Teaching and Research

\subsection{The "modern factory" style}

By optimizing the resources in schools, we have created an integrated teaching and research environment for educating people in our school, introduced the management and management concepts of modern factories into schools, and concentrated and simulated the production and business environment of modern factories to schools of the teaching process, and even some of the modern enterprise production, business management into the school, so that schools directly involved in the production and operation of the enterprise. Its culture is easy to control, its resources are easily coordinated, the quality of education guaranteed and the knowledge and abilities necessary for students to learn in a near-real environment [2].

\subsection{Teaching base}

Since it is impossible to establish various factories in schools to meet all the needs of personnel training, the educational environment and training methods in schools are different from those in social environments. Production, education and research combined with education entirely dependent on the implementation of engineering practice within the school, can not achieve the required teaching objectives. So you can use the way students go out, let students contact with society, understand the community, participate in economic construction. All colleges and universities should choose some advanced technology and equipment, advanced management, suitable for students to operate environmental conditions conducive to play a creative enterprise or scientific research institutes as a combination of production, education and research base. At the 
same time, the school can also employ business engineers and technicians as on-site part-time teachers, businesses can provide students with some jobs, so that students have the opportunity during school to enter the actual field of production, access to real vocational training and work experience, and job Work to complete a certain production tasks [2].

\subsection{The joint school-run type}

Schools need capital investment, improve school conditions; companies need high-quality personnel to improve their competitiveness in the market, the actual interests of both school-enterprise drive, so that the joint school to achieve a "win-win "The goal. This is one of the most important characteristics of the combination of production, study and research. There are many successful cases in some foreign universities. The school relies on technical strength and scientific research strength to maintain close contact with the enterprise. Through the cooperative education commission jointly established by the school and the enterprise, the school regularly discusses the relevant issues and coordinates the relationship between the school and the enterprise and the personnel training. Its advantage is that on the one hand it can be convenient for enterprises to select and train qualified personnel to help students get employed successfully; on the other hand, through such on-the-job training, students gain work experience and benefit greatly.

\section{The Advantages of Integration of Production, Teaching and Research}

(1) Cooperative education of production, study and research as a means and method of combining theory with practice, classroom learning and work practice, it is a process of perfecting the personnel training function of traditional education mode. It is with the traditional teaching methods and personnel training methods are complementary and mutually reinforcing relationship. The cooperative education of production, study and research does not exclude the theoretical knowledge of traditional modes of education, classroom teaching and school education, and has not moved schools and classrooms to factories and enterprises. Its purpose is to better help students master the theoretical knowledge, improve the efficiency of classroom learning, to make up for the deficiencies and deficiencies of school education in the overall quality of students. The adaptability of production, education and research cooperation education should be very broad, not only suitable for low-level schools and low-level education. But not only suitable for high-level research universities, but also for general teaching-oriented universities. It is a good method and means for higher vocational colleges with a clear career orientation [3].

(2) As a means and measure to improve the function of school education, it has universal adaptability. The cooperative education of production, study and research is widely used in engineering disciplines such as engineering, architecture and design due to its obvious advantages in helping students acquire practical skills. The results of this study are obviously beneficial to the future employment and professional orientation of students. When these visible and tangible advantages are displayed in front of people, it is easy to confine it to the field of applied science, thus affecting the cooperative development of production, learning and research in all disciplines of higher education [3].

(3) In the course of the development of cooperative education of production, study and research, there is another kind of educational thought that plays an important role in establishing cooperative education based on comprehensive quality education. The idea is that people who lack the experience of work and social practice can not achieve more comprehensive development. Therefore, every student must take "learning a job-learning" way to complete their studies. Each graduates should have experience working in a number of social production areas and departments. The cooperative education of production, study and research is regarded as promoting overall quality. The most effective way of education. Therefore, based on the comprehensive quality education, the guiding ideology of cooperative education of production, study and research breaks the confines of the production, education and research cooperation limited to the applied disciplines. For academic disciplines, it is also possible to adopt the cooperative education of production, study and research Methods and means. 


\section{Industry-University-Institute Integration to Promote Curriculum System Reform}

(1) Through the cooperative education of production, study and research, the motivation of student learning is greatly enhanced. Many students put forward new requirements for teaching content, hoping to increase the knowledge content that meets the needs of the first line of production. Students' practical ability, innovative ability and entrepreneurial spirit are tempered and improved. Students participate in the cooperative education of production, study and research. By combining with practice, Social contact, working with all kinds of personnel, experiencing the hardships of the cause, cultivating the ability to analyze and solve problems, and to work together in a collective way. The competitiveness of students' employment has been enhanced. Students learn practical skills in hands-on practice and learn the theoretical knowledge that must be available in practicing skills acquisition. Explore students 'potentials and develop their personalities in the process of students' autonomous learning; let them experience the experiences of opening up wisdom and enhancing self-confidence, and make our education a success in shaping education [2].

(2) Promote teaching reform and improvement of teacher's professional level

As the main body of learning, students should take the action ability in vocational situation as the goal, take the project working process in the learning situation based on the professional situation as the way, and the interactive action between teachers and students and students as the way to stress learning The process of self-construction of middle school students is the process of learning, which is based on the assessment of the action ability formed by the integration of professional ability, method ability and social ability. Students are also capable of independently planning, implementing and evaluating vocational practical problems. Teachers are the organizers and coordinators of the learning process. A good teacher should be the designer of the learning situation and the director of the learning stage. The cooperative education of production and learning pays great attention to the cultivation of the overall quality of the students mainly based on the ability cultivation. There is a big difference between the training forms and the traditional ones. Therefore, we must reform the teaching plan, break the traditional curriculum structure, adjust the proportion of theoretical teaching and practical teaching, effectively promote the reform of teaching content and teaching methods; teachers in the process of guiding the cooperative education of production, research and get more and practical contact Opportunities to solve the problems raised by the business sector, so that the choice of research topics. Facing the actual situation, scientific research has been improved.

(3) Mutual benefit between school and enterprise The process of production, study and research cooperation education is also a process of mutual benefit between school and enterprise. The enterprises have benefited from solving technical problems, technical training and obtaining cheap labor. Schools have benefited from establishing internship bases, obtaining certain financial support and building "double divisions" teams. In order to create a real drilling fluid environment for students, the school cooperates with the drilling company's practical experts to develop the curriculum. It uses the two educational resources of schools and enterprises to create learning situations and conditions for the implementation of the curriculum. Schools and enterprises work closely together to educate people. Work together to develop student jobs, typical tasks and teaching methods; cooperation in the construction of teaching materials and teaching resources, co-develop student internship management system, work out the development and evaluation of student learning outcomes Approach; in the process of enterprise environment curriculum, co-management and monitoring of teaching and learning; school and enterprise part-time each other to build co-managed teaching, job training and technical cooperation in the development of part-time team, schools and businesses in close cooperation and mutual benefits and seek develop together[3].

\section{Conclusions}

Based on the research of some theoretical and practical workers over the years, this paper expounds the basic conceptions and characteristics of cooperative education of production, study and research, the advantages of implementing cooperative education of production, education and 
research as well as the education, teaching and social effects achieved. Therefore, through a perfect talent cultivation mechanism for cooperative education in production, education and research, we will give full play to their own respective advantages in resources in universities, research institutes and enterprises, break through the existing "closed" training model and effectively and effectively cultivate people with innovative spirit And innovative ability of high-quality personnel, so as to implement innovative national development strategy to provide personnel assurance and intellectual support.

\section{References}

[1] Zhang Liangfeng, Zeng Yongwei. Based on engineering practice teaching research-based education optimization model [J]. China higher education, 2009 (23): 43-44

[2] Zhang Lian. Theoretical issues of cooperative education of industry, university and research and practice in our country [J]. Vocational and Technical Education, 2002 (34): 21-25.

[3] Wu Yan. China's higher occupation colleges and universities cooperative education research and thinking [D]. Hebei Normal University, 2007.

[4] Chen Yanhui. Discussion on the theory and practice of cooperative education of production, study and research [J]. Modern Education Science, 2007 (S1): 13-14. Construction technology of long-span continuous bridge in bridge construction [J]. Low Carbon World, 2016 (34): 210-211. 